\title{
Did Sirach See Himself as a Prophet?
}

Jolanta Judyta Pudełko PDDM, Profetyzm w Księdze Syracha (Studia Biblica Lublinensia 21; Lublin: Wydawnictwo KUL 2020). Pp. 424. 35 PLN. ISBN 978-83-8061-854-1

\section{Andrzej Piwowar}

The John Paul II Catholic University of Lublin

andrzej.piwowar@kul.pl

https://orcid.org/0000-0001-9316-1791

\begin{abstract}
Aвstract: The article reviews J.J. Pudełko's book-length study titled Profetyzm $w$ Księdze Syracha [Prophetism in the Book of Sirach]. Following an initial presentation of the book, the author focuses on its methodological aspect and offers an assessment of its merit before discussing the main thesis of Pudełko in the context of other scholarly opinions on the issue. Based on her meticulous analysis of prophetism in the works of the Jerusalem sage, Pudełko concludes that Sirach saw himself as an heir to the Old Testament prophets, as his role of a sage corresponded to the tasks fulfilled earlier by prophets. Although this argument is questioned by most contemporary analysts of the Book of Sirach, still Pudełko's book constitutes an important intervention in the debate on Sirach's prophetic self-awareness.
\end{abstract}

KEYwORDS: prophetism, prophet, the Book of Sirach, sage-prophet

Jolanta Judyta Pudetko is a well-known Polish biblical scholar who published one scientific ${ }^{1}$ monograph and thirty-one scientific articles and chapters in multi-author monographs. A specific field of her research interests is the Book of Sirach, to which she devoted as many as fifteen out of her thirty-one scientific articles, ${ }^{2}$ not counting the mentioned monograph

1 In chronological order: J.J. Pudełko, Wierny przyjaciel lekarstwem życia (Syr 6,16). Koncepcja przyjaźni w Księdze Syracydesa (RSBibl; Warszawa: Vocatio 2007).

2 In chronological order: J.J. Pudełko, "Czym jest utrata przyjaciela? O problemach krytyczno-tekstualnych Księgi Syracydesa," CT 77/3 (2007) 43-62; J.J. Pudełko, "Przyjaźń w świecie starożytnym i w Księdze Syracydesa," Przybliżyto się Królestwo Boże. Księga pamiątkowa dla Księdza Profesora Romana Bartnickiego w 65. Rocznice urodzin (ed. W. Chrostowski) (Warszawa: Stowarzyszenie Biblistów Polskich 2008) 433-450; J.J. Pudełko, “(Nie)obecność kobiet w Pochwale ojców (Syr 44-49)," «Niewiastę dzielna kto znajdzie?» (Prz 31,10). Rola kobiet w biblijnej historii zbawienia (eds. A. Kubiś - K. Napora) (ABL 14; Lublin: Wydawnictwo KUL 2016) 195-211; J.J. Pudetko, "The (Apparent) Absence of Women in the Praise of the Ancestors (Sir 44-49)," BibAn 6 (2016) 107-126; J.J. Pudełko, "Powołanie kobiety według Syracydesa," VV 19 (2011) 89-109; J.J. Pudełko, "Wychowanie według Syracydesa," VV 21 (2012) 83-107; J.J. Pudełko, "Aaron jako nauczyciel świadectw (Syr 45,17)," VV 28 (2015) 133-153; J.J. Pudełko, “Geneza Samarytan a ich obraz w Syr 50,25-26," WST 28/1 (2015) 168-188; J.J. Pudełko, "Od pogardy do idealizacji - obraz kobiet w Księdze Syracha," BPTh 8 (2015) 67-80; J.J. Pudełko, "Roztropna gościnność w Księdze Syracha," BPTh 9 (2016) 87-98; J.J. Pudełko, “Dawid jako organizator kultu w Pochwale Ojców (Syr 47,8-10)," BPTh 10 
and the habilitation thesis reviewed in this article. The above statistical summary clearly shows that the Warsaw biblical scholar is one of the best experts in the work of Sirach, also referred to as the sage from Jerusalem, not only in Poland but also in the world. Considering the fact that the Book of Sirach, belonging to the deuterocanonical books, is not a center of research interest, though it must be admitted that in recent years the interest in this biblical book has increased significantly in Poland as well. The latest scientific monograph written by Jolanta Judyta Pudełko was accepted with even bigger contentment and interest. The monograph titled Profetyzm $w$ Księdze Syracha [Prophetism in the Book of Sirach] was reported by her as the basis for habilitation proceedings. This article is devoted to the assessment of the thesis, and especially to its main thesis, which the author presented as a summary of her research on the phenomenon of prophetism in the Book of Sirach. This article will consist of a general presentation of the discussed habilitation thesis, methodological comments, substantive assessment, and a discussion of the main research conclusion of the presented monograph. The formal assessment of the discussed thesis will be omitted, as it does not present any major reservations (only a small number of typos can be noticed, there are also a few stylistic errors, in two places the division of the Greek text and its translation into stichoi has not been preserved), so it does not require more attention.

\section{General Presentation of the Book}

Monograph by Jolanta Judyta Pudełko titled: Prophetism in the Book of Sirach was published by the John Paul II Catholic University of Lublin in the scientific series Studia Biblica Lublinensia in 2020 as the 21 st volume of this series. Its main body consists of four chapters that fully correspond to the title of the monograph: chapter I: "Profetyzm w okresie Drugiej Świątyni i judaizmu rabinicznego jako kontekst Syrachowego nauczania o prorokach i proroctwie" [Prophetism in the Period of the Second Temple and Rabbinic Judaism as the Context of Sirach's Teaching on Prophets and Prophecy] (pp. 31-66), chapter II: "Prorocy i proroctwo w Księdze Syracha (Prolog; Syr 1 - 43)" [The Prophets and Prophecy in the Book of Sirach (Prologue; Sir 1-43)] (pp. 67-132), chapter III: "Prorocy i proroctwo w Pochwale ojców. Mojżesz i Prorocy Wcześniejsi (Syr 44,3 - 48,14)" [Prophets and Prophecy in the Praise of the Ancestors. Moses and the Earlier Prophets (Sir 44:3-48:14)] (pp. 133-279) and chapter IV: "Prorocy i proroctwo w Pochwale ojców. Prorocy Późniejsi (Syr 48,20 - 49,25)" [Prophets and prophecy in the Praise of the Ancestors. Later Prophets (Sir 48:20-49:25)] (pp. 281-347). They were preceded by a Table of Contents in Polish (pp. 7-10) and English (pp. 11-14), a List of abbreviations (pp. 15-18), and

(2017) 263-283; J.J. Pudełko, “Dlaczego Adam zamyka Pochwatę Ojców (Syr 44-49)?," BibAn 7 (2017) 441-457; J.J. Pudełko, "Mędrzec - ideał dla wybranych? Tożsamość mędrca w Księdze Syracha," WST 31/1 (2018) 94-106; J.J. Pudełko, "Obecność anioła w opowiadaniu o najeździe Sennacheryba na Jerozolimę w Syr 48,21," Bib An 9 (2019) 269-284; J.J. Pudełko, "Periodyzacja dziejów Izraela w Pochwale ojców Księgi Syracha (Syr 44-49)," VV 35 (2019) 37-74. 
an Introduction (pp. 19-29). The whole work is summed up in an Ending written in Polish (pp. 349-356) and English (pp. 357-364), followed by a Bibliography (pp. 365-387), an Index of authors (pp. 389-394), and an Index of sources (pp. 395-424).

The title of the monograph under review is precise and clearly indicates the research problem (prophetism) which the thesis by Pudetko addresses and the scope in which it will be examined and analyzed (The Book of Sirach). The title is fully consistent with its content, which is confirmed by the titles and content of individual chapters of the reviewed scientific thesis.

The bibliography is extensive (pp. 365-387) and includes the most important publications relating to the analyzed research problem. It needs to be highlighted that the author used not only foreign literature (especially publications in English, but also German, Italian, French, and Spanish) but also Polish studies. This might be surprising to a reader, but in recent years a disturbing trend has been observed - especially among young scientists consisting of authors referring to foreign literature on the issues and topics analyzed and researched by them, often omitting publications in Polish, making thus useless the hard work of Piotr Ostański, who has received the degree of doctor habilitatus and who has been publishing a bibliography of Polish biblical ${ }^{3}$ studies for many years, as well as the achievements and contribution to the development of research on the Holy Scriptures of Polish biblical scholars. It can be seen that The Book of Sirach. Text, Concordance and an Analysis of the Vocabulary (The Historical Dictionary of the Hebrew Language; Jerusalem: Academy of the Hebrew Language - Shrine of the Book 1973), concordance to the Hebrew text of Dominique Barthélemy and Otto Rickenbacher ${ }^{4}$ and the Greek text of Edwin Hatch and Henry A. Redpath ${ }^{5}$ as well as references to the website www.bensira.org, where all excerpts from the original Book of Sirach are published, along with their English translation were not included in the Bibliography. Of course, the author of the thesis was not obliged to use the above-mentioned Book of Sirach's Hebrew text publication or the website, because the fragments of original texts were quoted after Pancratius C. Beentjes. ${ }^{6}$ However, since she referred to the publications of Norbert Peters ${ }^{7}$ and Rudolf Smend from the beginning of the ${ }^{8} 20$ th century, it would be expected that she would enrich her study also with the abovementioned publications. Also, in the Bibliography two most important - fundamental for

3 See P. Ostański, Bibliografia biblistyki polskiej. I-II. 1945-1999. III-IV. 2000-2009. V. 2010-2013/ 2014. VI-VII. 2014-2017 (Series Bibliographica 1-4; Poznań: Uniwersytet im. Adama Mickiewicza. Wydział Teologiczny. Redakcja Wydawnictw 2002, 2010, 2015, 2019).

4 See D. Barthélemy - O. Rickenbacher, Konkordanz zum hebräischen Sirach mit syrisch-hebräischem Index (Göttingen: Vandenhoeck \& Ruprecht 1973).

5 See E. Hatch - H.A. Redpath, A Concordance to the Septuagint and the Other Greek Versions of the Old Testament (Including the Apocryphal Books), 2 ed. (Grand Rapids, MI: Baker Books 1998).

6 See P.C. Beentjes, The Book of Ben Sira in Hebrew. A Text Edition of All Extant Hebrew Manuscripts and a Synopsis of All Parallel Hebrew Ben Sira Texts (VTSup 68; Leiden - New York - Köln: Brill 1997).

7 See N.Peters, Der jüngst wiederaufgefundene hebräische Text des Buches Ecclesiasticus, untersucht, herausgegeben, übersetzt und mit kritischen Noten versehen (Freiburg im Breisgau: Herder 1902); N. Peters, Das Buch Jesus Sirach oder Ecclesiasticus. Übersetzt und erklärt (EHAT 25; Münster: Aschendorff 1913).

$8 \quad$ See R. Smend, Die Weisheit des Jesus Sirach erklärt (Berlin: Reimer 1906). 
Greek LXX - Greek-English dictionaries by Johan Lust - Erick Eynikel - Katrin Hauspi ${ }^{9}$ and Takamitsu Muraoki ${ }^{10}$ were not included. It seems that Pudetko has given the meanings of Greek words using the dictionary developed by Zofia Abramowiczówna (only that dictionary of the Greek language is given in the Bibliography), ${ }_{11}^{11}$ which is a good dictionary of the Greek language, but in the field of classical, not biblical, Greek. When it is possible, in research on the biblical Greek text, biblical Greek dictionaries should be used first, because they take into account the specificity of biblical koine, and only if necessary, use dictionaries based on classical Greek. As for the dictionaries for the biblical Hebrew language, the author of the reviewed monograph refers to the two most important and best dictionaries by David J.A. Clines (in the Bibliography, however, reference is made only to the first five volumes of this dictionary, while it has nine volumes with indexes) ${ }^{12}$ and Ludwig Koehler Walter Baumgartner - Johann J. Stamm. ${ }^{13}$

The Bibliography has not been divided into parts traditionally adopted in Polish scientific literature: sources, commentaries, detailed studies, general studies as well as dictionaries and lexicons. The author of the thesis adopted the increasingly spreading trend of compiling a bibliography in alphabetical order. Of course, there is no obligation to divide the bibliography into the parts indicated above ${ }^{14}$ but using it makes the bibliography itself clearer and certainly shows what kind of publications the author of a given scientific work mainly relied on (scientific articles, monographs, dictionary and encyclopedic entries).

\section{Methodological Notes}

In the Introduction (pp. 28-29), Pudełko described in detail the research method that she adopted in her thesis in order to perform an exegetical-theological analysis of selected fragments from the Book of Sirach that concern prophetism and prophets. In the beginning,

9 SeeJ. Lust-E. Eynikel-K. Hauspie, $A$ Greek-English Lexicon of the Septuagint. I. $A$-I. II. $K-\Omega$ (Stuttgart: Deutsche Bibelgesellschaft 1992).

10 See T. Muraoka, A Greek-English Lexicon of the Septuagint (Louvain - Paris - Walpole, MA: Peeters 2009).

11 See Z. Abramowiczówna (ed.), Stownik grecko-polski (Warszawa: Państwowe Wydawnictwo Naukowe 1958-1965) I-IV.

12 See D.J.A. Clines (ed.), The Dictionary of Classical Hebrew (Sheffield: Sheffield Academic Press - Sheffield Phoenix Press 1993-2011) I-IX.

13 See L. Koehler - W. Baumgartner - J.J. Stamm (eds.), The Hebrew and Aramaic Lexicon of the Old Testament (Leden - New York - Köln: Brill 1994-2000) I-V = L. Koehler - W. Baumgartner - J. J. Stamm (eds.), Wielki stownik hebrajsko-polski i aramejsko-polski Starego Testamentu (ed. [Polish Edition] P. Dec) (Warszawa: Vocatio 2008) I-II.

14 "Individual items are listed in accordance with the Polish alphabet [...] The division of bibliography, especially when it comes to doctoral dissertations and books, is agreed upon with the supervisor or publisher. The usual division is split into two parts. There is 'source literature' that contains studies and their analysis on which the work puts focus, and 'auxiliary literature' where texts on the subject are mentioned. In any case, it is better to avoid numerous divisions" (S. Bazyliński, Wprowadzenie do studium Pisma Świętego [Introduction to the Study of the Holy Scriptures], 2 ed. [Kielce: Jedność 2019] 288). 
she noted that there is no single version of the text of the sage from Jerusalem and even the critique of the text is not able to establish the text that would be the original text or similar to it. "This work was written in Hebrew, but it is the Greek version of this work that is fully preserved and canonical. For this reason, the main, but not the only, research text in this monograph will be the Greek version of the Book of Sirach." ${ }^{15}$ In the further part of the presentation of the research method, the author of the thesis declares that she will treat the Hebrew version of Sir as an auxiliary text (p. 28). Pudełko, writing about the original work of the sage from Jerusalem, states that, unfortunately, the Hebrew text is very often damaged and incomplete, therefore in the footnotes, she will cite contemporary reconstructions of the Hebrew text, but she will treat them only as research hypotheses. In footnote no. 36 on p. 29 she declares to refer to the works of the Hebrew text published by Charles Mopsik ${ }^{16}$ and Víctor Morla. ${ }^{17}$ However, she did not take into account the reconstructions of the Hebrew text proposed by Hebrew-language researchers such as Elia S. Hartom ${ }^{18}$ or Moshe Z. Segal. ${ }^{19}$ Personally, I would omit these modern reconstructions of the Hebrew text in exegetic-theological analysis, because, as the author of the thesis notes, they are research hypotheses..$^{20}$ They are hypotheses, i.e., only more or less probable recreations of the alleged original text, based mainly on the Greek and Syriac versions. Certainly, these proposals are very interesting from the point of view of text criticism and techniques of its reconstruction, but since the purpose of the analysed monograph is completely different, Pudetko could simply not refer to them, and therefore it was not necessary in her work.

Unfortunately, the Hebrew text we currently know does not contain the entirety of the Book of Sirach. To this day, only or as much as $3 / 4$ of the sage of Jerusalem's works have been discovered. This is why Pudełko writes: "Where the Hebrew text is not available, the ancient Syriac translation was proposed for comparison. It is the early Semitic translation of the original Hebrew. It's also a valuable resource in instances where the Greek and Hebrew texts vary." ${ }^{\prime 1}$ The author is well aware of how difficult and complex the relations between the various versions of the Book of Sirach's text known today are, since she writes: "[...] the presence of the Hebrew text of the Book of Sirach also sheds new light on the Greek text, as it allows us to understand the concept of a translator who was after all the interpreter of the Hebrew text."22 On this canvas arises the methodological question of why the author of the thesis referred to the Syriac version (in a particularly extensive way

15 J.J. Pudełko, Profetyzm w Księdze Syracha (Studia Biblica Lublinensia 21; Lublin: Wydawnictwo KUL 2020) 28.

16 See C. Mopsik, La Sagesse de ben Sira. Traduction de l'hébreu, introduction et annotation (Les Dix Paroles; Lagrasse: Verdier 2003).

17 See V. Morla, Los manuscritos hebreos de Ben Sira (Asociación Bíblica Española 59; Estella: Editorial Verbo Divino 2012).

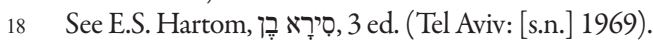

19 See M.Z. Segal, השלם סירא בן ספרו ספר, 3 ed. (Jerusalem: Bialik 1973).

20 Pudekko, Profetyzm w Księdze Syracha, 28-29.

21 Pudełko, Profetyzm w Księdze Syracha, 29.

22 Pudełko, Profetyzm w Księdze Syracha, 29. 
in the analysis of Sir 24:30-34, the original version of which is unknown), since it is a late translation of the Hebrew text which was most likely made by a Christian and includes references to the Greek text, which greatly diminishes its value as a witness to the original text ${ }^{23}$. One could get the impression that Pudełko puts significantly too much value on the meaning of the Syriac version. ${ }^{24}$ This problem can be noticed in paragraph 3 chapter IV, where despite the fact the author of the thesis previously declared that she would refer to the Syriac version only in the analysis of the Greek text, which is unknown in the Hebrew version, whereas the original text, i.e., Hebrew, Sir 49:8-9 is known. The question arises, that since in paragraph 3.2 the author references the Syriac version, why doesn't she reference it in paragraph 3.4, where she did the exegetic analysis of Sir 49:8-9?

Since none of the main language versions of the Book of Sirach (neither Greek, ${ }^{25}$ nor Syriac much less Latin) is a translation of the original text in today's sense (faithful rendering of the original in another language), ${ }^{26}$ it is therefore necessary to consider whether attempting to "create - recreate" the text of the original work of the sage of Jerusalem in order to reach his original thought and message makes sense. In my opinion, one should focus on only one version of the text and possibly compare it to others. However, a general rule should be adopted, perhaps too simplifying of the complex relations between the individual versions of the Sir text, that priority should be given to the Greek text (as Pudełko did in her habilitation thesis), because we know it in its entirety, and it is the canonical version of the Book of Sirach.

In the aforementioned habilitation thesis, the author was for the majority of the analysed texts of Sir faithful to the primacy she accorded to the Greek text and to making it the main version of the work of Sirach on which she based her analysis. However, in some cases, one can notice a deviation from this adopted initial methodological assumption. Although only in a few cases, it can be noticed in the reviewed monograph, that its author begins her analysis with the Hebrew version, not the Greek one, which was supposed to be the main

23 See N. Calduch-Benages - J. Ferrer - J. Liesen, La sabiduría del escribe (Biblioteca midrásica 26; Estella: Verbo Divino 2003)39-41; H. Langkammer, Księga Syracha. Wstęp-przektad z oryginatu - komentarz - ekskursy (PST 8/5; Poznań: Pallottinum 2020) 40; J. Marböck, Jesus Sirach 1-23 (HThKAT; Freiburg - Basel - Wien: Herder 2010) 26; M.D. Nelson, The Syriac Version of the Wisdom of Ben Sira Compared to the Greek and Hebrew Materials (SBL 107; Atlanta, GA: Scholars Press 1988) 6-7, 131-132; M.C. Palmisano, Siracide. Introduzione, traduzione e commento (Nuova Versione della Bibbia dai Testi Antichi 34; Cinisello Balsamo: Edizioni San Paolo 2016) 21; W.T. van Peursen, Language and Interpretation in the Syriac Text of Ben Sira (Monographs of the Peshitta Institute Leiden. Studies in the Syriac Versions of the Bible and Their Cultural Contexts 16; Leiden - Boston, MA: Brill 2007) 37; A. Piwowar, "Storia testuale del libro del Siracide," Roczniki Teologiczne 55/1 (2008) 43-47; P.W. Skehan - A.A. Di Lella, Wisdom of Ben Sira (AB 39; New York - London - Toronto: Doubleday 1987) 57.

24 "Sir is a free, sometimes imprecise or even incorrect translation from a Hebrew source text. This indicates that the translator knew Hebrew, but this knowledge appears to be limited, because more than once he misinterpreted his Hebrew source" (van Peursen, Language and Interpretation, 73-74).

25 See A.Minissale, La versione greca del Siracide. Confronto con il testo ebraico alla luce dellattività midrascica e del metodo targumico (AnBib 133; Roma: Pontificio Istituto Biblico 1995).

26 See B.G. Wright, No Small Difference. Sirach's Relationship to Its Hebrew Parent Text (SBL. Septuagint and Cognate Studies Series 26; Atlanta, GA: Scholars Press 1989). 
one. For example, in paragraph 6.1 chapter III she based the delimitation of Sir 48:1-11 on the Hebrew text (p. 235). Moreover, it can be noticed that she sometimes refers to Hebrew words or syntagmas first, not to Greek ones, in the exegetic analysis. These are, of course, minor methodological inconsistencies that could be easily ignored, but in a scientific paper at the habilitation level, one should expect "iron rigorism" in approaching various versions of the work of the sage of Jerusalem.

In the reviewed monograph, one can notice yet another kind of methodological inconsistency concerning the scope of the carried-out analyses. In paragraph 1.3 chapter IV the author unnecessarily discusses the structure of the entire pericope of Sir 48:47-25, i.e., the presentation of King Hezekiah and the prophet Isaiah (p. 286), since earlier, i.e., in paragraph 1.1 she wrote: "This analysis is intended to present only the prophet Isaiah" (p. 284). In paragraph 1 chapter IV the author of the thesis analysed only the verses referring to the prophet, i.e., Sir 48:20cd-25, rightly omitting the text concerning King Hezekiah, with which the description of the figure of Isaiah is connected. However, in paragraph 2 chapter IV, which discusses the figure of Jeremiah, she no longer adhered to this rule and also analysed Sir 49:4-6 on the last kings, and not just Sir 49:7, which directly describes Jeremiah.

Defining the research method on which the exegetic-theological analysis will be based, Pudełko writes:

\begin{abstract}
The exegetic procedure in the analysis of the texts will use both a diachronic and a synchronic approach. In the diachronic approach, elements of the historical-critical method, such as the history of text transmission, will be used. It will appear in the comparative analysis of the Hebrew and Greek texts, which, on the basis of the differences between the texts, will present its historical and theological development. The synchronic approach will be expressed in the analysis of the literary context of the pericopes, their delimitation, and finally the analysis of texts in terms of literary values. Another important element of these analyses will be their intertextuality. ${ }^{27}$
\end{abstract}

By making the research method described in such a general way more specific, the author of the thesis describes in great detail the individual research stages of the texts, which she will analyse in the following way: 1. showing the closest context, 2. translating the Greek, Hebrew and possibly Syriac versions into Polish, showing the differences between textual variants, 3. literary analysis (rhetorical figures, syntactic issues, repetitions, and thematic changes) and 4. exegesis of a given text-based on semantic and intertextual analysis. The research method adopted by Pudełko is correct. It should be emphasized that she applied it in an almost exemplary way (with minor shortcomings - as will be discussed in point 3. Substantive assessment - and methodological inconsistencies, which do not significantly affect the assessment of the entire monograph). In an almost exemplary way, because one can notice in the exegetic-literary analyses the lack of syntactic analysis declared in the description 
of the research method, especially in the Greek text, which due to its specificity requires much more attention to syntactic problems than the Hebrew language.

An important aspect of the reviewed monograph is its intertextuality, to which the author referred especially in chapter III and IV, where she discusses earlier and later prophets. By referring to the texts of other biblical books of the Old Testament (the Pentateuch, historical and prophetic books), the analysis of the individual characters presented in the last two chapters of the thesis is more complete and deeper. It also makes it possible to show successive prophets in relation to the accounts of them in other inspired books, and through this research procedure to make a comparison between the source text to which Sirach referred and the interpretation of the sage prophet in question. It should be emphasised that the comparative analysis is deep and solid, which allows us to somewhat understand the mind of the sage of Jerusalem and to not only learn about the sources he used in his study of individual characters, but also know how he presented them, i.e., what he highlighted in their activities, what he omitted, and what role he assigned to them in the history of Israel.

In the part devoted to the presentation of the research method she will use in her work, Pudełko states:

The Greek text and the verse numbering used in this work come from the Göttingen Septuagint, a scientific study of the Greek text of the book, edited by Jospeh Ziegler. This means that the verse numbering in several marked places will differ from the one present in the Millennium Bible (MB), to which the Polish reader is used, and which is based on the LXX edition prepared by Alfred Rahlfs and Robert Hanhart. ${ }^{28}$

The author of the monograph adapted to the trend visible in scientific research on the Greek version of the Book of Sirach, represented by many scientists who prefer and use in their publications the numbering proposed by the aforementioned editor of the critical edition of the Greek text of the Book of Sirach - Joseph Ziegler. ${ }^{29}$ Certainly, as the author noticed herself, in some cases it will cause problems with finding the correct text translated into Polish and it may cause quite a lot of confusion. Shouldn't the numbering used in the translations of Sir into Polish be preserved so as to avoid aforementioned issues and difficulties that may lead to confusion and chaos, especially if the reader isn't familiar with the changed numbering system? The sheer number of issues the numbering of individual verses in different versions of Sir translations can cause is best demonstrated by Friedrich V. Reiterer's synopsis of the numbering of the most important versions and translations of Sir. ${ }^{30}$ The issue regarding the verses' numbering can be observed in the thesis in relation to the numbering (recording) of the stichoi in Greek and Hebrew in the case of Sir $48: 12 \mathrm{efGH}$

28 Pudełko, Profetyzm $w$ Księdze Syracha, 28.

29 See J.Ziegler, Sapientia Iesu Filii Sirach (Septuaginta. Vetus Testamentum Graecum 12/2; Göttingen: Vandenhoeck \& Ruprecht 1980).

30 See F.V. Reiterer, Zählsynopse zum Buch Ben Sira (FSBP 1; Berlin - New York: De Gruyter 2003). 
(pp. 267 and 273) where there are no stichoi ef in the Greek text. Stichoi Sir 48:12cdG correspond to $\operatorname{Sir} 48: 12 \mathrm{efH}$.

\section{Substantive Assessment}

The introduction covers all of the elements that should be included in this part of the scientific monograph (the subject and purpose of the study, status questionis, overview of the structure of work, and discussion on the research method used for the development of the topic or the research question). The author of the monograph, however, has not presented precisely the semantic fields of prophecy, especially these related to the Greek language, because she focused solely on words derived from the Greek root $\pi p \circ \phi \eta$-, i.e., the verb $\pi p \circ \phi \eta \tau \varepsilon \dot{v} \omega$ and the noun $\pi p \circ \phi \eta \tau \varepsilon i \alpha$ (see pp. 20-21), but she omitted the noun öpaбוs which is the Hebrew equivalent of מזרה (Sir 49:8) and 46:15). However, she presented the Hebrew semantic field 'prophecy' in a more accurate and exhaustive way,

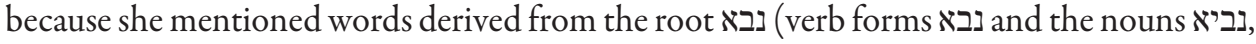

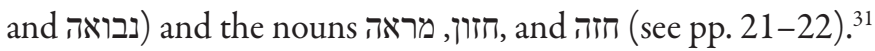

In the Introduction to her habilitation, Pudełko did not define prophetism, nor did she describe in more detail what it is exactly. She did not specify how it should be understood either. She only explained 'prophecy' in one sentence, which may go unnoticed by the reader, on the basis of the Greek semantic field and she mentioned how to understand the role and tasks of prophets, "These terms appear in Greek literature dated back to the 5 th century BC. They denote a man who proclaims something openly, a speaker, an early announcement, an ability to express God's will, an oracle, a proclamation of God's will, a response to an oracle, a prophetic office." ${ }^{32}$ The context of the quoted sentence may suggest that the description of prophetism refers solely to the Greek sphere with no connection to the biblical one. Moreover, if we apply this 'definition' of prophetism to the Bible, it should be noted that it greatly limits the biblical prophecy, as it narrows the definition down to just the announcement of God's will. The author of the monograph adjusts this initial and imperfect description - the definition of prophetism in the summary of chapter I, by writing: "The prophet can foresee the future, he leads other people and oversees the rulers' governance, he is the writer, he is the one who interprets God's word, and he is the mediator between God and the people." ${ }^{33}$ On p. 145 she states,

Even though various qualities of famous figures are mentioned in it, the entire scripture of Sir 44:3 can be applied to biblical prophets, because they had very important roles - not only religious, related to the preachment of God's word, but also political, military and social. All of it is related to

\footnotetext{
31 See Pudełko, Profetyzm w Księdze Syracha, 20-22.

32 Pudekko, Profetyzm w Kiędze Syracha, 20-21.

33 Pudełko, Profetyzm w Księdze Syracha, 64.
} 
the broad understanding of the prophetic identity that is present in the Bible itself, which describes prophets as people who mediate between God and the people on many different levels.

It would have been better if the author of the thesis had given and had emphasized clearly the definition of prophetism already in the Introduction. She could have also presented in a descriptive way what exactly was prophetism and how a prophet should be understood - his role and tasks both in the religious and socio-political context.

The structure of the paper is logical, coherent and fully corresponds to the topic of the thesis. However, it is problematic to discuss the Prologue of the Book of Sirach in chapter II, and not in chapter I. The author herself rightly recognizes that the Prologue is not an actual part of the work of the sage from Jerusalem, but it is the work of his grandson, who translated from Hebrew into Greek a book written by his grandfather - Sirach..$^{34}$ It seems more logical to put the references to prophetism found in the Prologue in chapter I than in chapter II because the Prologue focuses on both the role and importance of prophetism during the Second Temple period. The author emphasizes that the prophetic books were already greatly recognized back then because they are equated and placed on the same level as the Law. The Prologue seems to explain the reason why Sirach gave attention to the prophets and their activity in his work. However, the very opinion of the sage from Jerusalem about prophecy and the prophets is only explained indirectly.

If the aforementioned doubt regarding the Prologue of the Book of Sirach seems controversial and open to discussion, then paragraph 3 chapter I introduces a much more important and explicit substantive issue. Chapter I named "Prophetism in the period of the Second Temple and rabbinic Judaism as the context of the Sirachic teaching about prophets and prophecy," according to the author of the thesis, aims to introduce the historical and theological context of the teachings of the sage from Jerusalem about prophets and prophecy, as an essential comparative material to observe the specificity of the research question in his own scripture. ${ }^{35}$ In this chapter, Pudełko first analyzed the texts in the Hebrew Bible (paragraph 1) that refer to prophets and prophecy (Ps 74:9; Zech 1:4a; 13:2-3; references to the research question contained in Mal and Joel 3:1-2 and in the Chronicle). Next, she discussed references to prophets and prophecies in the LXX, i.e., 1 Macc, Dan $\left(\theta^{\prime}\right)$, and Wis (paragraph 2), and then she introduced ancient extra-biblical Jewish interpretations (paragraph 3) that consist of the works of Philo of Alexandria, Titus Flavius Josephus, the writings of Qumran, the apocalyptic writings and wills, and the rabbinic literature. The sequence in

See Pudełko, Profetyzm w Księdze Syracha, 69.

35 " [...] The first chapter of this study will be dedicated to the reality of prophetism during the Second Temple period and in the writings of rabbinic Judaism. This chapter will therefore present the historical and theological context of Syrach's teachings on prophets and prophecy, which is an essential comparative material for understanding the specificity of the research question posed by the author of the Book of Sirach. [...] In the first chapter, which provides the background for the research, the answers for the question about the existence and shape of the prophecy in the time of Sirach will be researched. The beliefs that were prevalent could have influenced the perception of this phenomenon by the sage from Jerusalem" (Pudełko, Profetyzm w Księdze Syracha, 26-27). 
which individual authors and literature are discussed in the last paragraph is quite surprising. One would expect a chronological order, i.e., the writings of Qumran, the apocalyptic writings and wills, Philo of Alexandria, Josephus, and the rabbinic literature. One should also consider whether the writings of Philo of Alexandria, Titus Flavius Josephus (the same applies to The Book of Sirach as well), and the rabbinic literature could be part of "the historical and theological context of Sirach's teachings on prophets and prophecy" (p. 26) because these works are more recent, and it is possible that the Wisdom of Sirach influenced them. On p. 48 the author in the introduction to paragraph 3 chapter I states "Although in the case of the latter [the writings of the rabbinic literature - the author's annotation] even though their transcription goes beyond $\mathrm{AD} 70$, the ideas in them arose much earlier and can illuminate the understanding of prophecy in the Hellenistic period." ${ }^{36}$ However, it is only a guess. This statement is too far-fetched. There is no certainty that these writings retained ideas that might have shed light on how the Jewish approached prophetism in Hellenistic times. The above statement may be a reasonable supposition only in respect of the scriptures from Qumran and the Book of Enoch, but not to the works of Philo of Alexandria, Titus Flavius Josephus, 2 Baruch (written at the end of the first century AD) and the writings of the rabbinic literature. Discussing the works of Philo of Alexandria, Titus Flavius Josephus and rabbinic literature as the context of Sirach's views on prophetism is methodologically and substantially unjustified and erroneous. The ending of paragraph 3.5 chapter I, in which the author ends her discussion about the rabbinic literature with reference to Christianity, is surprising. ${ }^{37}$

In the monograph, Pudełko does not include that many interpretations of the analyzed texts that may be deemed problematic. I do not agree with her statement that 1 Macc 4:45d-46 does not preach "about the complete absence of prophets but about the necessity of waiting for the right prophet to appear in the future" (p. 42). The Greek text of 1 Macc 4:46 preaches about a right place where the stones of the destroyed altar are to be laid ( $\dot{\varepsilon} \nu \tau \dot{\delta} \pi \omega \dot{\varepsilon} \pi \mathrm{i} \tau \eta \delta \varepsilon i \omega)$, not about the appropriate prophet. In the interpretation of 1 Macc 9:27, one should rather agree with David L. Petersen's opinion rather than the statement of the author of the thesis that, "1 Macc 9:27 indicates the temporary absence of the prophet, which is subject to change, rather than the permanence of this absence" (p. 43). The conclusion of Pudełko appears to be rather based on 1 Macc 14:41 and 4:46, the texts which she quotes as last references from the Book of Maccabees about prophets and prophecy, rather than from 1 Macc 9:27.

In the conclusion of chapter I the author, after discussing David E. Aune's four models of prophetism of the Second Temple period (Apocalyptic, Eschatological, Priestly, Wisdom; pp. 64-66) she writes: "In such a diverse space of Second Temple Judaism, finally appears Sirach and his reflection on prophecy, understood as a reflection on history and the present" (p. 66). The quoted sentence suggests that the sage from Jerusalem lived at

\footnotetext{
36 See Pudekko, Profetyzm $w$ Księdze Syracha, 27.

37 See Pudełko, Profetyzm $w$ Księdze Syracha, 62-63.
} 
a time when previously mentioned four forms of prophetism were already developed and coexisted side by side. It seems rather logical to assume that Sirach could have possibly contributed to the creation of the wisdom model of prophetism.

The translations of some Greek texts into the Polish language, which the author of the reviewed dissertation included in her publication, are debatable. It should be emphasized that she independently translated the analyzed texts of the Book of Sirach into Polish, which proves her good knowledge of biblical languages, and at the same time, it is an important and positive aspect of the reviewed monograph. Translation of biblical texts, especially the Greek ones, is a very difficult task, because it requires from a translator to have not only good knowledge of the vocabulary, but also perfect knowledge of the syntax and content of the work, which is translated into the modern language. In the dissertation by Pudełko, there are only a few texts that were translated in a debatable manner. One of them is the translation of Prolog 1-3 because the genitive words were translated as if they were nominatives in the Greek text. Based on the remarks related to the translation of Prolog it can be noted that Pudełko did not devote enough space and attention in her thesis for syntax analysis of the analyzed texts. This observation applies especially to the Greek version of Sir, because the Greek language, due to its specificity, allows much more often for different syntactic interpretations than the Hebrew language, and thus also for different translations of the Greek text. In the entire thesis, there is a visible lack of syntactic analysis of the discussed Greek texts and its elements, even where they are implicitly expressed, e.g., in relation to the participium $\delta \varepsilon \delta 0 \mu \varepsilon v \omega \nu$, which the author rightly treats as passivum theologicum, but without explaining why she claims that the law and the prophets "were given" by God. On p. 193 the form $\pi \eta \kappa \eta \kappa \sigma \varepsilon v \pi \eta \kappa \sigma \varepsilon \nu$ needs to be recognized as complex aorist. In the interpretation of Sir $46: 7$ one should have considered the possibility of translating infinitives in this verse as expressing effect, not only the goal (pp. 170, 194 and 197).

In paragraph 1 Pudetko inconsistently translates one of the key Old Testament Greek words for the Sir and Wisdom Tradition. One of these words is $\pi \alpha i \delta \varepsilon i \alpha$, which on p. 70 is translated as "instruction," whereas, on pp. 73, 77 and further, it is translated as "teach-

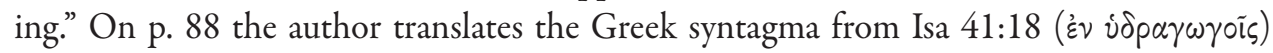
inconsistently with the meaning of the Greek noun appearing in her work, which meaning of 'waterworks' she had given earlier, since she took the translation 'in water fountains' from the Millennium Bible. Sir 36:22b was improperly translated because the noun $\varepsilon \dot{\delta} \delta$ oki $\alpha$ does not mean "benignancy," but "preference," which is confirmed by the translation of Ps 106:4 (p. 112) and analysis of this word on p. 112. In Sir 36:22 Pudetko translates a form of past tense $(\gamma \nu \dot{\omega} \sigma o v \tau \alpha \mathrm{l})$ as the imperative of the aorist ("[let them] know"), pp. 110 and 113. The verb $\kappa \alpha \tau \alpha \pi \alpha \dot{\omega} \omega$ (see Sir 45:3a) does not mean "to speed up," but "to withhold," which the author writes about on p. 155 as another possible meaning of this verb. The doctor habilitatus candidate inaccurately translated the text Sir 46:3 as "Who will oppose him?" (pp. 170 and 183), Sir 46:5b "when surrounded by enemies, he was in danger" (pp. 170 and 187), Sir 46:6a: "he struck a war into the nation" (pp. 170 and 190). While the above-mentioned reservations regarding the translation of the Greek text into 
Polish can be discussed, the translation of Sir 48:5-10 raises more serious objections. In the Greek version of the text, there is a series of six participles, five of which are substantiated. The author of the reviewed monograph translates them without any explanation of the syntactic nature as adjectival forms (see pp. 237-238). ${ }^{38}$ When justifying her translation, she stated that each of the verses discussed constitutes an anaphora (p. 248). It should be noted, however, that the actual anaphora is definitely only Sir 48:4. The preposition $i \pi \dot{o}$ in combination with the form of the verb in the passive voice expresses the ultimate acting factor, so the preposition in Sir 48:12cG should be translated "by" and not "because of" (p. 273).

In paragraph 2.1 chapter II the author presented the literary context of Sir 24:30-34, but did not perform a delimitation of the pericope she will be analyzing. Showing the structure of the text which Sir 24:30-34 is a part of, is not synonymous with delimiting this literary unit.

In chapter III the paragraph 1.3 title (similarly in paragraph 1.1) should not contain the word 'pericope, but instead, it should contain 'verse, because in this paragraph only one verse was analyzed, which does not constitute a separate pericope or a part of a pericope. It belongs, however, to Sir 44:3-6, as the author correctly pointed out on pp. 136 and 140. There is a visible methodological inconsistency here, because Pudełko analyzes only one verse in this paragraph - the one which includes a reference to prophecy, not the entire literary unit, as she did so far in chapter II.

In paragraph 4.4.2 chapter II verses Sir 46:17-18 were quite briefly discussed (pp. 219-221), as well as Sir 48:4b in paragraph 6.4.2 (p. 247; only five lines of text, specifically one sentence of commentary, not counting the reference to Greek and Hebrew text of this stichos).

Objections are raised by the interpretation of Sir 48:6b (p. 251), especially the statement that this stichos is about a death in bed.

It is untrue that Sir $48: 21 \mathrm{H}$ omits the action of an angel in saving Jerusalem from Sennacherib's hands (p. 293), because in version $\mathrm{H}$ of this verse the second stichos is missing, which in $\mathrm{G}$ talks about the action of the angel/messenger. The author probably based her opinion on the $S$ version, but this is only a supposition. It is also difficult to agree with the statement that the messenger of God in Sir 48:21bG is Isaiah (p. 294). Similarly (on p. 294), it is uneasy to agree with the statement that God in Sir 48:21bG acts through his word because the text of this stichos says nothing about the word of God and his action.

38 See W. Kraus - M. Karrer (eds.), Septuaginta Deutsch. Das griechische Alte Testament in deutscher Übersetzung (Stuttagrt: Deutsche Bibelgesellschaft 2009) 1157; A. Pietersma - B.G. Wright (eds.), A New English Translation of the Septuagint. And the Other Greek Translations Traditionally Included under that Title (New York - Oxford: Oxford University Press 2007) 759. 


\section{Main Thesis}

In the Conclusion, Pudełko, summarizing her considerations on the prophecies and prophets in Sir, makes a thesis that Sirach continues the activity of earlier prophets through inspired interpretation and updating of the Torah, the prophets and the scriptures. Just like prophets did, he passes the will of God to his contemporaries and guides them along the paths of fidelity to the Covenant, thus becoming a prophet-sage (p. 356). The author of the thesis describes the work of Sirach itself as a "wisdom prophecy" (p. 356). The above conclusions are reasonable and appropriate, although based only on Sir 24:30-34. I would suggest taking into account also Sir 51:13-30 and Sir 39:1-11 (the author of the thesis partially discusses this text in her work [paragraph 4 chapter II, pp. 115-132]). In addition, Pudełko should highlight and emphasize more the thesis she presented in the Conclusion, which is the result of her analysis and reflection on the prophecy in the Book of Sirach.

It should be emphasized that the above conclusion (thesis) of the author on the Prophetism in the Book of Sirach it is not novel or new. It was first formulated in 1906 by R. Smend: "Denn die Identifikation der Weisheit mit der jüdischen Religion ist gegen den Hellenismus gerichtet, in dessen Bekämpfung der Schriftgelehrte sich als sein Nachfolger der Propheten weiss. ${ }^{39}$ This idea was somewhat returned to in 2002 by Josef Schreiner, who claims that Sirach placed himself among the learned prophets teaching the Law. ${ }^{40}$ In 2005 Leo G. Perdue referred Sirach to prophets but in a different, less unequivocal and clear, way:

Ben Sira identifies himself neither as priest nor as prophet. Rather, he sees himself in his inspired state to be 'like' a prophet. Thus, for Ben Sira, there was Moses and the Tora, then the priests, then the prophets, and finally the chosen sages who continued to be the vehicle of inspiration for theocracy of the new Jerusalem. ${ }^{41}$

The analysed issues are treated similarly by John G. Snaith, ${ }^{42}$ Alexander A. Di Lella ${ }^{43}$ and Maria C. Palmisano. ${ }^{44}$ On the other hand, Gerhard Maier, O. Rickenbacher and

39 See Smend, Die Weisheit des Jesus Sirach erklärt, 215.

40 "Er stellt sich in die Reihe schriftgelehrter Propheten (vgl. Prolog), welche die Torah auslegen (vgl. Jos $1^{7.8}$ und Mal $3^{22}$ als bestimmenden Rahmen um das Corpus der »früheren « und »späteren « Propheten)" (J. Schreiner, Jesus Sirach 1-24 [NEchtB Altes Testament; Würzubrg: Echter 2002] 134).

41 See L.G. Perdue, "Ben Sira and the Prophets," Intertextual Studies in Ben Sira and Tobit. Essays in Honor of Alexander A. Di Lella, O. F. M. (CBQMS 38; Washington, D.C.: Catholic Biblical Association of America 2005) 138.

42 "[...] he feels that his inspiration is as compelling as that of the prophets before him" (J.G. Snaith, Ecclesiasticus or The Wisdom of Jesus Son of Sirach [Cambridge Bible Commentaries on the Apocrypha; Cambridge: Cambridge University Press 1974] 126).

43 "Finally, Ben Sira says he will 'pour out [...] instruction like prophecy' (v 33a), i.e., he is aware of his own inspiration from God, as the prophets of old were of theirs (See Jer 1:7,9); and like them, he utters his wisdom for the benefit of others" (Skehan - Di Lella, Wisdom of Ben Sira, 338).

44 "Sembra che Ben Sira, usando come termine di confronto della propria opera l'attivitá profetica, consideri che il proprio lavoro abbia un valore analogo ad essa, ritenendosi compositore autentico e quindi ispirato" (Palmisano, Siracide, 237-238). 
Johannes Marböck reject the possibility of associating Sirach with prophets. ${ }^{45}$ Ralph Hildesheim in his monograph on the prophets in the Book of Sirach does not refer to the issue of Sirach identifying with the prophets ${ }^{46}$ because in his study he only analysed the texts about the prophets contained in The Praise of the Ancestors. On the other hand, Helge Stadelmann does not conclusively and unequivocally resolve the question of whether Sirach identified himself with the earlier prophets and whether he saw his activity as a continuation of the activity of the prophets. ${ }^{47}$ Georg Sauer on the basis of Sir 24:33 claims that the teachings of the sage of Jerusalem merely exist within a prophetic context, ${ }^{48}$ whereas Luis Alonso Schökel states that Sirach's teachings can be compared to prophecy. ${ }^{49}$

The above very briefly presented the analysis of the development of the problem whether Sirach considered himself a continuator of the prophets clearly indicates that this issue is quite known and discussed by other researchers of Sirach's work. As such, it is not novum, however, it should be noted that Pudełko has made a thorough and comprehensive analysis of the prophetism phenomenon in the Book of Sirach, which has not yet been done with such great accuracy and in relation to the entire work (and even beyond - analysis of the references to prophetism contained within the Prologue). Rudolf Smend, like other researchers whose opinions have been cited above, based his statement only on a simple conclusion, which he drew from the text of Sir 24:33. The author of Prophetism in the Book of Sirach supported her conclusion with a thorough analysis of the entire work and all references therein to prophecy and prophets. For this reason, she is an important and significant, though not ultimately conclusive, voice in the discussion of the prophetic self-awareness of the sage of Jerusalem.

\section{Summary}

Jolanta Judyta Pudełko's habilitation thesis, despite the methodological inconsistencies mentioned in the previous points of the review, should be assessed very highly. It is an exegetically mature work, although there are a few methodological inconsistencies in it that many probably will not notice. The reason they appeared in the reviewed thesis is that

45 See G. Maier, Mensch und freier Wille. Nach den jüdischen Religionsparteien zwischen Ben Sira und Paulus (WUNT 12; Tübingen: Mohr [Siebeck] 1971) 42; J. Marböck, Weisheit im Wandel. Untersuchungen zur Weisheitstheologie bei Ben Sira (BZAW 272; Berlin - New York: De Gruyter 1999) 80; O. Rickenbacher, Weisheits Perikopen bei Ben Sira (OBO 1; Freiburg/Schweiz: Universitätsverlag Freiburg/Schweiz Göttingen: Vandenhöck \& Ruprecht 1973) 170-171.

46 See R. Hildesheim, Bis daß ein Prophet aufstand wie Feuer. Untersuchungen zum Prophetenverständnis des Ben Sira (Trier theologische Studien 58; Trier: Paulinus 1996).

47 See H. Stadelmann, Ben Sira als Schriftgelehrter. Eine Untersuchung zum Berufsbild des vor-makkabäischen Söfêr unter Berücksichtigung seines Verhältnisses zu Priester-, Propheten- und Weisheitslehrertum (WUNT 2/6; Tübingen: Mohr [Siebeck] 1980) 177-188.

48 See G. Sauer, Jesus Sirach / Ben Sira (ATD. Apokryphen 1; Göttingen: Vandenhoeck \& Ruprecht 2000) 185.

49 See L.A. Schökel - J.M. Valverde - J. Mateos, Proverbios y Eclesiastico (Colección Los Libros Sagrados 15; Madrid: Cristiandad 1968) 232. 
the author in her monograph used three different language versions (Greek, Hebrew, and Syriac) of the Book of Sirach, which on the one hand caused the aforementioned inconsistencies, and on the other hand enormously enriched the exegetical analysis of the texts. Even the other aforementioned inconsistencies in the translation of texts (especially Greek) and sometimes objectionable interpretations cannot affect the high rating of the reviewed book, because, on the one hand, they are marginal, and on the other hand they are discussable and probably explainable in direct confrontation with the author of the monograph. In her habilitation thesis, Pudełko proved her very good exegetic and linguistic preparation (both in relation to biblical and modern languages) as well as scientific maturity and reliability. Her monograph is the first full and complete study of prophetism in the Book of Sirach and a significant contribution to biblical literature, not only in Polish but also worldwide. The final thesis of the thesis could have been given more prominence in the Conclusion, so as to be a clearer conclusion of the conducted exegetic analyses. It is not new, but it is the first time it has been developed so extensively and supported by very detailed analyses of texts relating to the prophets and prophecy in the works of the sage of Jerusalem.

\section{Bibliography}

Abramowiczówna, Z. (ed.), Stownik grecko-polski (Warszawa: Państwowe Wydawnictwo Naukowe 1958-1965) I-IV.

Barthélemy, D. - Rickenbacher, O., Konkordanz zum hebräischen Sirach mit syrisch-hebräischem Index (Göttingen: Vandenhoeck \& Ruprecht 1973).

Bazyliński, S., Wprowadzenie do studium Pisma Świętego, 2 ed. (Kielce: Jedność 2019).

Beentjes, P.C., The Book of Ben Sira in Hebrew. A Text Edition of All Extant Hebrew Manuscripts and a Synopsis of All Parallel Hebrew Ben Sira Texts (Supplements to Vetus Testamentum 68; Leiden - New York - Köln: Brill 1997).

The Book of Ben Sira, http://www.bensira.org [access: 27.08.2021].

The Book of Ben Sira. Text, Concordance and an Analysis of the Vocabulary (The Historical Dictionary of the Hebrew Language; Jerusalem: Academy of the Hebrew Language - Shrine of the Book 1973).

Calduch-Benages, N. - Ferrer, J. - Liesen, J., La sabiduría del escribe (Biblioteca midrásica 26; Estella: Verbo Divino 2003).

Clines, D.J.A. (ed.), The Dictionary of Classical Hebrew (Sheffield: Sheffield Academic Press - Sheffield Phoenix Press 1993-2011) I-IX.

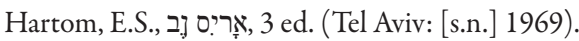

Hatch, E. - Redpath, H.A., A Concordance to the Septuagint and the Other Greek Versions of the Old Testament (Including the Apocryphal Books), 2 ed. (Grand Rapids, MI: Baker Books 1998).

Hildesheim, R., Bis daß ein Prophet aufstand wie Feuer. Untersuchungen zum Prophetenverständnis des Ben Sira (Trier theologische Studien 58; Trier: Paulinus 1996).

Koehler, L. - Baumgartner, W. - Stamm, J.J. (eds.), The Hebrew and Aramaic Lexicon of the Old Testament (Leden - New York - Köln: Brill 1994-2000) I-V = Koehler, L. - Baumgartner, W. - Stamm, J.J. (eds.), Wielki stownik hebrajsko-polski i aramejsko-polski Starego Testamentu (ed. [Polish Edition] P. Dec) (Warszawa: Vocatio 2008) I-II.

Kraus, W. - Karrer, M. (eds.), Septuaginta Deutsch. Das griechische Alte Testament in deutscher Übersetzung (Stuttagrt: Deutsche Bibelgesellschaft 2009). 
Langkammer, H., Ksiega Syracha. Wstęp - przektad z oryginatu - komentarz - ekskursy (Pismo Święte Starego Testamentu 8/5; Poznań: Pallottinum 2020).

Lust, J. - Eynikel, E. - Hauspie, K., A Greek-English Lexicon of the Septuagint. I. $A$ - I. II. $K$ - $\Omega$ (Stuttgart: Deutsche Bibelgesellschaft 1992).

Maier, G., Mensch und freier Wille. Nach den jüdischen Religionsparteien zwischen Ben Sira und Paulus (Wissenschaftliche Untersuchungen zum Neuen Testament 12; Tübingen: Mohr [Siebeck] 1971).

Marböck, J., Weisheit im Wandel. Untersuchungen zur Weisheitstheologie bei Ben Sira (Beihefte zur Zeitschrift für die alttestamentliche Wissenschaft 272; Berlin - New York: De Gruyter 1999).

Marböck, J., Jesus Sirach 1-23 (Herders Theologischer Kommentar zum Alten Testament; Freiburg - Basel Wien: Herder 2010).

Minissale, A., La versione greca del Siracide. Confronto con il testo ebraico alla luce dell'attività midrascica e del metodo targumico (Analecta Biblica 133; Roma: Pontificio Istituto Biblico 1995).

Mopsik, C., La Sagesse de ben Sira. Traduction de l'hébreu, introduction et annotation (Les Dix Paroles; Lagrasse: Verdier 2003).

Morla, V., Los manuscritos hebreos de Ben Sira (Asociación Bíblica Española 59; Estella: Verbo Divino 2012).

Muraoka, T., A Greek-English Lexicon of the Septuagint (Louvain - Paris - Walpole, MA: Peeters 2009).

Nelson, M.D., The Syriac Version of the Wisdom of Ben Sira Compared to the Greek and Hebrew Materials (Society of Biblical Literature 107; Atlanta, GA: Scholars Press 1988).

Ostański, P., Bibliografia biblistyki polskiej. I-II. 1945-1999. III-IV. 2000-2009. V. 2010-2013/2014. VI-VII. 2014-2017 (Series Bibliographica 1-4; Poznań: Uniwersytet im. Adama Mickiewicza. Wydział Teologiczny. Redakcja Wydawnictw 2002, 2010, 2015, 2019).

Palmisano, M.C., Siracide. Introduzione, traduzione e commento (Nuova Versione della Bibbia dai Testi Antichi 34; Cinisello Balsamo: San Paolo 2016).

Perdue, L.G., "Ben Sira and the Prophets," Intertextual Studies in Ben Sira and Tobit. Essays in Honor of Alexander A. Di Lella, O.F.M. (The Catholic Biblical Quarterly. Monograph Series 38; Washington, D.C.: Catholic Biblical Association of America 2005) 132-154.

Peters, N., Der jüngst wiederaufgefundene hebräische Text des Buches Ecclesiasticus, untersucht, herausgegeben, übersetzt und mit kritischen Noten versehen (Freiburg im Breisgau: Herder 1902).

Peters, N., Das Buch Jesus Sirach oder Ecclesiasticus. Übersetzt und erklärt (Exegetisches Handbuch zum Alten Testament 25; Münster: Aschendorff 1913).

van Peursen W.T., Language and Interpretation in the Syriac Text of Ben Sira (Monographs of the Peshitta Institute Leiden. Studies in the Syriac Versions of the Bible and Their Cultural Contexts 16; Leiden - Boston, MA: Brill 2007).

Pietersma, A. - Wright, B.G. (eds.), A New English Translation of the Septuagint. And the Other Greek Translations Traditionally Included under that Title (New York - Oxford: Oxford University Press 2007).

Piwowar, A., "Storia testuale del libro del Siracide," Roczniki Teologiczne 55/1 (2008) 31-53.

Pudełko, J.J., "Czym jest utrata przyjaciela? O problemach krytyczno-tekstualnych Księgi Syracydesa," Collectanea Theologica 77/3 (2007) 43-62.

Pudełko, J.J., Wierny przyjaciel lekarstwem życia (Syr 6,16). Koncepcja przyjaźni w Księdze Syracydesa (Rozprawy i Studia Biblijne; Warszawa: Vocatio 2007).

Pudełko, J.J., "Przyjaźń w świecie starożytnym iw Księdze Syracydesa," Przybliżyto się Królestwo Boże. Ksiega pamiątkowa dla Księdza Profesora Romana Bartnickiego w 65. Rocznicę urodzin (ed. W. Chrostowski) (Warszawa: Stowarzyszenie Biblistów Polskich 2008) 433-450.

Pudełko, J.J., “Powołanie kobiety według Syracydesa," Verbum Vitae 19 (2011) 89-109.

Pudełko, J.J., "Wychowanie według Syracydesa," Verbum Vitae 21 (2012) 83-107.

Pudełko, J.J., “Aaron jako nauczyciel świadectw (Syr 45,17),” Verbum Vitae 28 (2015) 133-153.

Pudełko, J.J., "Od pogardy do idealizacji - obraz kobiet w Księdze Syracha," Biblica et Patristica Thoruniensia $8(2015) 67-80$.

Pudełko, J.J., "Pochodzenie Samarytan a ich obrazw Syr 50,25-26," Warszawskie Studia Teologiczne 28/1 (2015) $168-188$. 
Pudełko, J.J., "The (Apparent) Absence of Women in the Praise of the Ancestors (Sir 44-49)," The Biblical Annals 6 (2016) 107-126.

Pudełko, J.J., "(Nie)obecność kobiet w Pochwale ojców (Syr 44-49)," «Niewiastę dzielną kto znajdzie?» (Prz 31,10). Rola kobiet w biblijnej historii zbawienia (eds. A. Kubiś - K. Napora) (Analecta Biblica Lublinensia 14; Lublin: Wydawnictwo KUL 2016) 195-211.

Pudełko, J.J., "Roztropna gościnność w Księdze Syracha," Biblica et Patristica Thorunensia 9 (2016) 87-98.

Pudełko, J.J., "Dawid jako organizator kultu w Pochwale Ojców (Syr 47,8-10)," Biblica et Patristica Thoruniensia 10 (2017) 263-283.

Pudełko, J.J., "Dlaczego Adam zamyka Pochwatę Ojców (Syr 44-49)?,” The Biblical Annals 7 (2017) 441-457.

Pudełko, J.J., "Mędrzec - ideał dla wybranych? Tożsamość mędrca w Księdze Syracha," Warszawskie Studia Teologiczne 31/1 (2018) 94-106.

Pudełko, J.J., “Obecność anioła w opowiadaniu o najeździe Sennacheryba na Jerozolimę w Syr 48,21," The Biblical Annals 9 (2019) 269-284.

Pudełko, J.J., "Periodyzacja dziejów Izraela w Pochwale ojców Księgi Syracha (Syr 44-49)," Verbum Vitae 35 (2019) 37-74.

Pudełko, J.J., Profetyzm w Księdze Syracha (Studia Biblica Lublinensia 21; Lublin: Wydawnictwo KUL 2020).

Reiterer, F.V., Zählsynopse zum Buch Ben Sira (Fontes et Subsidia ad Bibliam Pertinentes 1; Berlin - New York: De Gruyter 2003).

Rickenbacher, O., Weisheits Perikopen bei Ben Sira (Orbis Biblicus et Orientalis 1; Freiburg/Schweiz: Universitätsverlag Freiburg/Schweiz - Göttingen: Vandenhöck \& Ruprecht 1973).

Sauer, G., Jesus Sirach / Ben Sira (Das Alte Testament Deutsch. Apokryphen 1; Göttingen: Vandenhoeck \& Ruprecht 2000).

Schökel, L.A. - Valverde, J.M. - Mateos, J., Proverbios y Eclesiastico (Colección Los Libros Sagrados 15; Madrid: Cristiandad 1968).

Schreiner, J., Jesus Sirach 1-24 (Die Neue Echter Bibel Altes Testament 38; Würzubrg: Echter 2002).

Segal, M.Z., מלשה אריס ןב רפס, 3 ed. (Jerusalem: Bialik 1973).

Skehan, P.W. - Di Lella, A.A., Wisdom of Ben Sira (The Anchor Bible 39; New York - London - Toronto: Doubleday 1987).

Smend, R., Die Weisheit des Jesus Sirach erklärt (Berlin: Reimer 1906).

Snaith, J.G., Ecclesiasticus or The Wisdom of Jesus Son of Sirach (Cambridge Bible Commentaries on the Apocrypha; Cambridge: Cambridge University Press 1974).

Stadelmann, H., Ben Sira als Schriftgelehrter. Eine Untersuchung zum Berufsbild des vor-makkabäischen Söfêr unter Berücksichtigung seines Verhältnisses zu Priester-, Propheten- und Weisheitslehrertum (Wissenschaftliche Untersuchungen zum Neuen Testament 2/6; Tübingen: Mohr [Siebeck] 1980).

Wright, B.G., No Small Difference. Sirach's Relationship to Its Hebrew Parent Text (Society of Biblical Literature. Septuagint and Cognate Studies Series 26; Atlanta, GA: Scholars Press 1989).

Ziegler, J., Sapientia Iesu Filii Sirach (Septuaginta. Vetus Testamentum Graecum 12/2; Göttingen: Vandenhoeck \& Ruprecht 1980). 